\title{
Supplementation Effects of Ground Cassava and Cassava Leaves with Different Ratios on In Vitro Digestibility of Rice Straw Based-Diet
}

\author{
Muhammad Rizqi Hariz Daulay ${ }^{1}$, Dimas Hand Vidya Paradhipta ${ }^{1, *}$, Cuk Tri \\ Noviandi ${ }^{1}$, Ali Agus ${ }^{1}$, Andriyani Astuti ${ }^{1}$, Karen Harper ${ }^{2}$ \\ ${ }^{1}$ Faculty of Animal Science, Universitas Gadjah Mada, Jl. Fauna No.3 Bulaksumur, Yogyakarta, 55218, Indonesia \\ ${ }^{2}$ School of Agriculture and Food Science, University of Queensland, Gatton Campus, 4343, Australia \\ *Corresponding author.Email: dimas.hvp@ugm.ac.id
}

\begin{abstract}
The present study investigated the supplementation effects of ground cassava (GC) and cassava leaves (CL) with different ratios on digestibility of rice straw (RS) based-diet using in vitro technique. Two stages of in vitro ruminal digestibility were prepared and applied with different dietary treatments following: CON, consisted of $20 \%$ RS and $80 \%$ GC; T1, consisted of $20 \% \mathrm{RS}, 70 \% \mathrm{GC}$, and $10 \% \mathrm{CL}$; T2, consisted of $20 \% \mathrm{RS}, 60 \% \mathrm{GC}$, and $20 \% \mathrm{CL}$; T3, consisted of $20 \% \mathrm{RS}, 50 \% \mathrm{GC}$ and $30 \% \mathrm{CL}$; and T5, consisted of $20 \% \mathrm{RS}, 40 \% \mathrm{GC}$, and $40 \% \mathrm{CL}$. Each dietary treatment was prepared in quadruplicate. All dietary treatments were incubated into rumen buffer along with three blanks for analysis of ruminal digestibility (in vitro first stage), and then continued into chloride acid solution with pepsin incubation for analysis of total digestibility (in vitro first and second stages). Previously, the rumen fluid was collected from two Bali steers that fed Pennisetum purpureum and commercial concentrate at $8: 2$ ratio. Both stages were conducted at $39^{\circ} \mathrm{C}$ for $48 \mathrm{~h}$, respectively. In the ruminal digestibility, an increasing ratio of $\mathrm{CL}$ was reported to decrease $(\mathrm{P}<0.05)$ dry matter digestibility (DMD) and organic matter digestibility (OMD) of diet. Digestibility of crude protein (CPD) in the rumen was highest $(\mathrm{P}<0.05)$ in dietary $\mathrm{T} 3$, followed by dietary $\mathrm{T} 2$, dietary $\mathrm{T} 1$, and then dietary $\mathrm{T} 3$ and $\mathrm{T} 4$, consecutively. Supported with results of ruminal digestibility, an increasing ratio of $\mathrm{CL}$ also decreased $(\mathrm{P}<0.05)$ DMD and OMD of diet in the total digestibility. Moreover, it also decreased $(\mathrm{P}<0.05)$ CPD of diet in the total digestibility. Therefore, the present study concluded that dietary treatment consisting of $70 \% \mathrm{GC}$ and $10 \% \mathrm{CL}$ with $20 \%$ RS presented the most optimum ratio resulting the highest digestibility through in vitro technique.
\end{abstract}

Keywords: Cassava leaves, Ground cassava, Rice Straw, Supplementation ratio, In vitro digestibility.

\section{INTRODUCTION}

The study of nutrient balance in the diet is important to maintain animal growth, especially considering the use of local feeds for animal diet. In Indonesia, rice straw (RS) is commonly used as roughage source for ruminant diet that is cheap and available during a year. In addition, cassava is widely planted and become an alternative to supply the requirement of feed in the field as energy source. Ground cassava (GC) contain crude protein (CP) at $1.86-3.84 \%$, crude fiber at $2.93-3.91 \%$ [1] and provide almost $3000 \mathrm{kcal}$ energy [2]. Besides that, cassava leaves (CL) also can be used as animal feed due to containing high nutrient quality. The CL contain $\mathrm{CP}$ at $17.7-24 \%$, neutral detergent fiber at 59.6-66.2\%, and acid detergent fiber at 41.8-54.6\% [3]. With low NDF concentration and High CP concentration, CL can be applied as protein source for animal diet.

The RS based-diet is generally applied by almost of ruminant's farmers in Indonesia. However, RS can not be used as single feed due to poor nutrient content for animal maintenance. The use of RS for animal diet needs the supplementation of another sources, such as energy and protein feed. The information of nutrient balance among GC and CL was in limited study for RS based-diet. Several supplementary ratios among GC and CL were investigated in the present study to know its effect on digestibility using RS based-diet through two stages of in vitro technique. Two stage of in vitro digestibility 
consists of ruminal incubation and pepsin incubation [4], which can help to estimate the total digestibility of diet. Therefore, the present study was aimed to know the supplementation effect of GC an CL on digestibility including dry matter digestibility (DMD), organic matter digestibility (OMD), and crude protein digestibility (CPD) of RS based-diet using two stages of in vitro technique.

\section{MATERIALS AND METHOD}

\subsection{In Vitro Incubation}

Fresh RS, GC, and CL were dried into $55^{\circ} \mathrm{C}$ for $48 \mathrm{~h}$ and then ground to pass $1 \mathrm{~mm}$ screen according to previous study [5]. Dietary treatments were prepared with different supplementation ratios of GC and CL following: CON, consisted of $20 \% \mathrm{RS}$ and $80 \% \mathrm{GC}$; T1, consisted of $20 \% \mathrm{RS}, 70 \% \mathrm{GC}$, and $10 \% \mathrm{CL}$; T2, consisted of $20 \% \mathrm{RS}, 60 \% \mathrm{GC}$, and $20 \% \mathrm{CL}$; T3, consisted of $20 \% \mathrm{RS}, 50 \% \mathrm{GC}$ and $30 \% \mathrm{CL}$; and T5, consisted of $20 \% \mathrm{RS}, 40 \% \mathrm{GC}$, and $40 \% \mathrm{CL}$. In the first stage of in vitro incubation, rumen fluid was obtained from cannulated Bali steer fed Pennisetum purpureum and commercial concentrate with 8:2 ratio. Rumen fluid was collected before morning feeding and filtered with PeCap screen. Rumen buffer was prepared by mixture of filtered rumen fluid and McDougall solution at 1:4 ratio. Each dietary treatment at 0.5 gram was placed into incubation bottle $(100 \mathrm{~mL})$ and applied $50 \mathrm{~mL}$ of rumen buffer with four replications. The incubation bottle was gassed with $\mathrm{CO}_{2}$ and closed tightly. All incubation bottles along with three blanks were incubated for $48 \mathrm{~h}$ at $39^{\circ} \mathrm{C}$. After 48 of incubation, $6 \mathrm{~mL}$ of $\mathrm{HCL}$ and $2 \mathrm{~mL}$ of $5 \%$ pepsin were added into incubation bottle for second stage of in vitro incubation. In the second stage of in vitro incubation, the incubation was also continued for $48 \mathrm{~h}$ at $39^{\circ} \mathrm{C}$. The ruminal digestibility (first stage of in vitro incubation) dan total digestibility (first and second stages of in vitro incubation) were determined in the present study. All procedures for in vitro incubation followed the protocol of Tilley and Terry [4].

\subsection{Laboratory Analysis}

Chemical composition of RC, GC, CL, and all dietary treatments were determined before conducting in vitro incubation. Dry matter (DM) was determined by drying $10 \mathrm{~g}$ of sample into a forced-draft oven at $105^{\circ} \mathrm{C}$ for $24 \mathrm{~h}$ (method 934.01) and OM was determined with a muffle furnace at $550^{\circ} \mathrm{C}$ for $5 \mathrm{~h}$ (method 942.05). The CP were determined by the producer of Kjeldahl (method 984.13) using $\mathrm{N}$ analyzer, while $\mathrm{EE}$ were determined by the procedure of Soxhlet (method 920.39). The CF was analyzed by boiled sample in acid and basal solution (method 987.10). All protocols to analyze chemical compositions followed AOAC [6]. The DMD, OMD, and CPD of ruminal digestibility and total digestibility were determined and calculated according to protocol of Tilley and Terry [4].

\subsection{Statistical Analysis}

Data in the present study were analyzed using one-way ANOVA procedure of Software Statistical Product and Service Solution (SPSS, version 16). Mean separation was performed by Duncan's Multiple Range Test. The significant differences were declared at $\mathrm{P}<0.05$.

Table 1. Chemical compositions of dietary treatments in the present study

\begin{tabular}{|c|c|c|c|c|c|c|c|c|}
\hline \multirow{2}{*}{ Item } & \multirow{2}{*}{$\begin{array}{l}\text { Rice } \\
\text { straw }\end{array}$} & \multirow{2}{*}{$\begin{array}{l}\text { Ground } \\
\text { cassava }\end{array}$} & \multirow{2}{*}{$\begin{array}{l}\text { Cassava } \\
\text { leaves }\end{array}$} & \multicolumn{5}{|c|}{ Dietary treatments ${ }^{1}$} \\
\hline & & & & CON & T1 & T2 & T3 & T4 \\
\hline Dry matter & 83.6 & 81.8 & 28.6 & 94.3 & 92.0 & 92.6 & 93.1 & 92.2 \\
\hline Organic matter & 78.0 & 96.1 & 91.7 & 93.4 & 92.6 & 91.9 & 91.2 & 90.4 \\
\hline Crude protein & 4.85 & 2.21 & 18.3 & 5.16 & 6.34 & 8.17 & 8.58 & 9.87 \\
\hline Ether extract & 2.87 & 2.64 & 16.0 & 2.00 & 2.05 & 2.90 & 4.27 & 5.30 \\
\hline Crude fiber & 35.9 & 2.21 & 12.4 & 9.19 & 10.0 & 12.0 & 13.3 & 15.5 \\
\hline Nitrogen-free extract & 34.4 & 91.7 & 45.1 & 77.1 & 74.1 & 68.9 & 65.1 & 59.8 \\
\hline Total digestible nutrient & 18.4 & 81.0 & 69.2 & 61.4 & 57.9 & 54.2 & 51.83 & 50.37 \\
\hline
\end{tabular}

${ }^{1} \mathrm{CON}$, diet with $80 \%$ ground cassava; T1, diet with $70 \%$ ground cassava and $10 \%$ cassava leaves; T2, diet with $60 \%$ ground cassava and $20 \%$ cassava leaves; T3, diet with $50 \%$ ground cassava and $30 \%$ cassava leaves; and T5, diet with $40 \%$ ground cassava, and $40 \%$ cassava leaves. All diet applied $20 \%$ rice straw. 
Table 2. Supplementation effects of ground cassava and cassava leaves with different ratios on in vitro digestibility

\begin{tabular}{|l|l|l|l|l|l|}
\hline \multirow{2}{*}{ Item } & \multicolumn{4}{l|}{ Dietary treatments } \\
\cline { 2 - 6 } & CON & $\mathrm{T} 1$ & $\mathrm{~T} 2$ & $\mathrm{~T}$ & $\mathrm{~T}$ \\
\hline Ruminal digestibility & & & & & \\
\hline Dry matter & $72.61^{\mathrm{a}} \pm 1.23$ & $68.15^{\mathrm{b}} \pm 1.16$ & $63.81^{\mathrm{c}} \pm 0.32$ & $57.50^{\mathrm{d}} \pm 0.10$ & $51.15^{\mathrm{e}} \pm 0.88$ \\
\hline Organic matter & $73.54^{\mathrm{a}} \pm 0.86$ & $69.03^{\mathrm{b}} \pm 1.14$ & $65.36^{\mathrm{c}} \pm 0.70$ & $58.88^{\mathrm{d}} \pm 1.04$ & $53.24^{\mathrm{e}} \pm 0.77$ \\
\hline Crude protein & $29.57^{\mathrm{c}} \pm 0.72$ & $30.85^{\mathrm{b}} \pm 0.94$ & $32.64^{\mathrm{a}} \pm 0.56$ & $22.58^{\mathrm{d}} \pm 0.98$ & $23.60^{\mathrm{d}} \pm 1.34$ \\
\hline Total digestibility & & & & & \\
\hline Dry matter & $82.79^{\mathrm{a}} \pm 0.34$ & $76.97^{\mathrm{b}} \pm 1.10$ & $73.65^{\mathrm{c}} \pm 0.29$ & $69.79^{\mathrm{d}} \pm 1.25$ & $65.74^{\mathrm{e}} \pm 1.75$ \\
\hline Organic matter & $83.39^{\mathrm{a}} \pm 0.78$ & $78.21^{\mathrm{b}} \pm 0.93$ & $73.74^{\mathrm{c}} \pm 0.11$ & $69.26^{\mathrm{d}} \pm 1.02$ & $64.47^{\mathrm{e}} \pm 1.87$ \\
\hline Crude protein & $67.49^{\mathrm{a}} \pm 0.52$ & $60.76^{\mathrm{b}} \pm 1.49$ & $61.16^{\mathrm{b}} \pm 0.34$ & $56.95^{\mathrm{c}} \pm 1.51$ & $54.48^{\mathrm{d}} \pm 2.01$ \\
\hline
\end{tabular}

${ }^{1} \mathrm{CON}$, diet with $80 \%$ ground cassava; T1, diet with $70 \%$ ground cassava and $10 \%$ cassava leaves; T2, diet with $60 \%$ ground cassava and $20 \%$ cassava leaves; T3, diet with $50 \%$ ground cassava and $30 \%$ cassava leaves; and T5, diet with $40 \%$ ground cassava, and $40 \%$ cassava leaves. All diet applied $20 \%$ rice straw.

${ }^{\mathrm{a} e} \mathrm{Mean}$ in the same row with different superscript differ significantly $(\mathrm{P}<0.05)$.

\section{RESULT AND DISCUSSION}

An increase of CL ratio in the diet increased $(\mathrm{P}<0.05)$ $\mathrm{CP}, \mathrm{EE}$, and CF concentrations (Table 1). This could be occurred due to the CL had a higher $(\mathrm{P}<0.05) \mathrm{CP}, \mathrm{EE}$, and $\mathrm{CF}$ concentrations than GC, which also supported with the results of previous studies [1-3]. In addition, the total digestible nutrient (TDN) and nitrogen-free extract (NFE) decreased $(\mathrm{P}<0.05)$ by an increase of $\mathrm{CL}$ proportion in the diet, which supported with the result of OM. The CL presented lower $(\mathrm{P}<0.05) \mathrm{OM}$, NFE, and TDN than GC, which higher ratio of CL in the diet decreased those chemical composition parameters.

In the ruminal digestibility, an increase of CL ratio in the diet was reported to decrease $(\mathrm{P}<0.05)$ DMD and OMD concentrations (Table 2 ). Dietary T2 resulted in the highest $(\mathrm{P}<0.05) \quad \mathrm{CPD}$ concentration of ruminal digestibility, followed by $\mathrm{T} 1$, then $\mathrm{T} 3$ and $\mathrm{T} 4$. In the total digestibility, an increase of CL ratio in the diet resulted in the decreases $(\mathrm{P}<0.05)$ of $\mathrm{DMD}$ and OMD concentrations. Dietary T1 and T2 had no difference on CPD concentration of total digestibility. In addition, both dietary $\mathrm{T} 1$ and $\mathrm{T} 2$ presented higher CPD concentration than dietary T3 and T4. A higher ratio of CL in the diet reduced the concentrations of $\mathrm{CP}, \mathrm{NFE}$, and TDN (Table $1)$, which could decrease the nutrient degradation by animals [5]. High concentration of NFE in diet indicated high concentration of soluble carbohydrate, which was easily to degrade in digestive tract of ruminant [7]. In addition, higher CP concentration in diet also could increase the degradation of protein in the digestive tract of ruminant [8]. Even though had good nutrient content,
CL also contained anti-nutritional compound, such as hydrocyanic acid (HCN) [4]. Supported with previous study [4], the high concentration of $\mathrm{HCN}$ in the diet could reduce the digestibility, both in the first and second stages of in vitro incubations. A higher ratio of CL could increase the concentration of HCN in the diet. It could be a main reason for the decrease of digestibility by the increase of CL ratio in the diet. Moreover, the presence of $\mathrm{HCN}$ was a cause for lower digestibility of all supplementary diets compared to $\mathrm{CON}$ diet

\section{CONCLUSION}

The present study concluded that dietary treatment consisting of $70 \% \mathrm{GS}, 10 \% \mathrm{CL}$, and $20 \%$ RS presented the most optimum ratio that resulted the greatest digestibility compared to another supplementary treatment through in vitro technique.

\section{ACKNOWLEDGMENTS}

This work has carried out with financial support from the Australian Centre for Indonesian Agricultural Research (ACIAR).

\section{REFERENCES}

[1] G.D. Prasetyo, A.D. Kartika, Mashudi, In vitro Digestibility of cassava mealfrom various types of cassava plants (Manihot utilissima), Jurnal Nutrisi Ternak Tropis 2(2) (2019) 33-37. DOI: https://doi.org/10.21776/ub.jnt.2019.002.02.1 
[2] Tilman, A., H. Hartadi, S. Reksohadiprodjo, S.Prawirokusumo, S. Lebdosoekjo. Basic of animal nutrition, Gadjah Mada University Press, Yogyakarta, Indonesia, 1991.

[3] A.O. Oni, C.F.I. Onwuka, O.M., Agribede, U.Y., Anele, O.O. Oduguwa, O.S. Onifade, Z.L. Tan. 2011. Chemical composition and nutritive value of four varieties of cassava leaves grown in SouthWestern Nigeria. Journal of Animal Physiology and Animal Nutrition 95 (2011) 583-590. DOI: 10.1111/j.1439-0396.2010.01086.x

[4] J.M.A. Tilley, R.A. Terry, A two-stage technique for the in vitro digestion of forage crops. Grass Forage Science 18 (1963) 104-111. DOI: 10.1111/j.1365-2494.1963.tb00335

[5] S.S. Lee, H.J. Lee, D.H.V. Paradhipta, Y.H. Joo, S.B. Kim, D.H. Kim, S.C. Kim, Temperature and microbial changes of corn silage during aerobic exposure, Asian-Australasian Journal of Animal Science $\quad 32 \quad$ (2019) 988-995. DOI: 10.5713/ajas.18.0566

[6] Associaton of Official Analytical Chemists, Official methods of analysis, $18^{\text {th }}$ Edition, AOAC International, USA, Washington, 2005

[7] A. Chesson, C.W. Forsberg, Polysaccharide degradation by rumen microorganisms, in: P.N. Hobson, C.S. Stewart (Eds.), The Rumen Microbial Ecosystem, Blackie Academic and Professional, London, UK, 1997, pp 329-381.

[8] R.J. Wallace, R. Onodera, M.A. Cotta, Metabolism of nitrogen-containing compounds, in: P.N. Hobson, C.S. Stewart (Eds.), The Rumen Microbial Ecosystem, Blackie Academic and Professional, London, UK, 1997, pp. 283-328. 